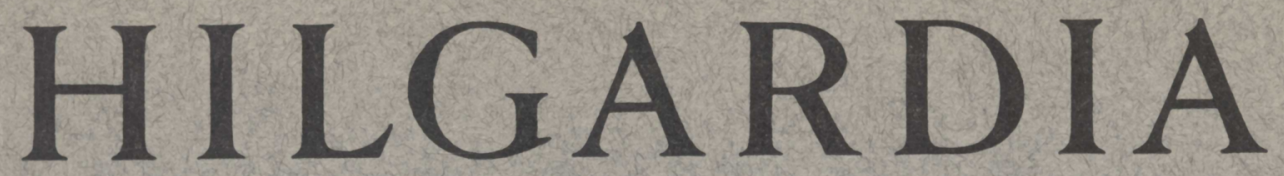

A Journal of Agricultural Science Published by the California Agricultural Experiment Station

\title{
THE EFFECTS OF PHOSPHORUS DEFICIENCY ON CITRUS
}

H. D. CHAPMAN and S. M. BROWN

\section{THE EFFECTS OF SULFUR DEFICIENCY ON CITRUS}

\author{
H. D. CHAPMAN and S. M. BROWN
}

\section{SPECIES OF STIGMINA AND STIGMELLA OCCURRING ON PLATANUS} DONALD J. SMITH and CLAYTON O. SMITH 


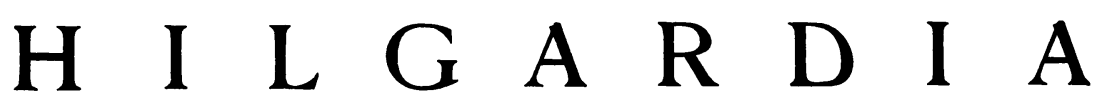

A Journal of Agricultural Science Published by

the California Agricultural Experiment Station

VoL. 14

NOVEMBER, 1941

No. 4

\section{THE EFFECTS OF PHOSPHORUS DEFICIENCY ON CITRUS ${ }^{1,2}$}

\author{
H. D. CHAPMAN ${ }^{3}$ AND S. M. BROWN
}

\section{INTRODUCTION}

INFORMATION CONCERNING the effects of mineral deficiencies and excesses on plants has proved of great value in the diagnosis of nutritional disorders in the field and has also provided many clues as to the function and interrelation of elements in plant metabolism and nutrition. In the case of citrus, knowledge of this subject, though extensive, is far from complete. Certain deficiencies, for example, have never been seen or produced on bearing trees; nor is it known, in many instances, which of the effects of a deficiency are primary and which secondary. Investigations concerned with various phases of citrus nutrition have led to the realization that a more thorough understanding of this subject is indispensable-is, in fact, a necessary cornerstone for further effective work. There are indications, too, that certain obscure physiological disorders affecting fruit production and fruit quality may be related to nutrition. Hence considerable experimental work has been carried out and is under way to extend our knowledge of the incipient and acute effects of deficiencies and excesses of mineral elements on the various species of citrus.

In connection with a soil-fertilizer experiment with young navelorange trees in large containers (55-gallon oil drums), acute phosphorus deficiency developed in one of the soils used. Since, to the knowledge of the authors, the effects of a lack of this element on bearing orange trees have never been described, an account of the onset and progressive stages of this disorder is set forth herein.

\footnotetext{
${ }^{1}$ Received for publication December 3, 1940.

${ }^{2}$ Paper no. 436, University of California Citrus Experiment Station, Riverside, California.

${ }^{3}$ Associate Professor of Agricultural Chemistry and Associate Chemist in the Experiment Station.

*Assistant Chemist in the Experiment Station.
} 


\section{EXPERIMENTAL PROCEDURE}

The fertilizer experiment referred to was begun in January, 1934, to determine whether large variations in the nitrogen, phosphorus, and potassium supply of soils would produce measurable effects on fruit quality.

Differential fertilizer treatments, as shown in table 1, were given duplicate cultures of each of two soils-one a calcareous Hanford fine sandy loam of low phosphate availability, from Santa Ana, California;

TABLE 1

Differential Fertilizer Treatments Given Soils in Oil Drums

\begin{tabular}{|c|c|c|c|c|c|c|c|c|}
\hline \multirow{3}{*}{$\begin{array}{l}\text { Hanford } \\
\text { fine sandy } \\
\text { loam } \\
\text { cultures }\end{array}$} & \multirow{3}{*}{$\begin{array}{l}\text { Sierra } \\
\text { loam } \\
\text { cultures }\end{array}$} & \multirow{3}{*}{ Fertilizer treatment } & \multicolumn{6}{|c|}{ Amounts applied } \\
\hline & & & \multicolumn{2}{|c|}{$\begin{array}{l}\text { Nitrogen } \\
\text { as N }\end{array}$} & \multicolumn{2}{|c|}{$\begin{array}{l}\text { Phosphorus } \\
\text { as } \mathrm{P}_{2} \mathrm{O}_{5}\end{array}$} & \multicolumn{2}{|c|}{$\begin{array}{l}\text { Potassium } \\
\text { as } \mathrm{K}_{2} \mathrm{O}\end{array}$} \\
\hline & & & $\begin{array}{c}\text { Per } \\
\text { oil } \\
\text { drum }\end{array}$ & $\begin{array}{c}\text { Rate } \\
\text { per } \\
\text { acre* }^{*}\end{array}$ & $\begin{array}{c}\text { Per } \\
\text { oil } \\
\text { drum }\end{array}$ & $\begin{array}{c}\text { Rate } \\
\text { per } \\
\text { acre } \\
\end{array}$ & $\begin{array}{c}\text { Per } \\
\text { oil } \\
\text { drum }\end{array}$ & $\begin{array}{c}\text { Rate } \\
\text { per } \\
\text { acre }\end{array}$ \\
\hline 1 and 2 & 13 and 14 & None. & $\begin{array}{c}\text { grams } \\
0.00\end{array}$ & $\begin{aligned} l b s . \\
0\end{aligned}$ & $\begin{array}{r}\text { grams } \\
0.0\end{array}$ & $\begin{array}{l}\text { lbs. } \\
0\end{array}$ & $\begin{array}{c}\operatorname{grams} \\
0.0\end{array}$ & $\begin{aligned} & \text { lbs. } \\
& 0\end{aligned}$ \\
\hline 3 and 4 & 15 and 16 & $\mathrm{~N}$ (calcium nitrate) & 13.75 & 482 & 0.0 & 0 & 0.0 & 0 \\
\hline 5 and 6 & 17 and 18 & $\begin{array}{c}\mathrm{NP}(\text { calcium nitrate and dicalcium } \\
\text { phosphate }) \ldots \ldots \ldots\end{array}$ & 13.75 & 482 & 136.5 & 4,784 & 0.0 & 0 \\
\hline 7 and 8 & 19 and 20 & $\begin{array}{r}\text { NK (calcium nitrate and potassium } \\
\text { sulfate) } \ldots \ldots \ldots \ldots \ldots \ldots \ldots\end{array}$ & 13.75 & 482 & 0.0 & 0 & 33.8 & 1,185 \\
\hline 9 and 10 & 21 and 22 & $\begin{array}{c}\text { NPK (calcium nitrate, dicalcium } \\
\text { phosphate, and potassium sul- } \\
\text { fate) } \ldots \ldots \ldots \ldots \ldots \ldots \ldots \ldots \ldots\end{array}$ & 13.75 & 482 & 136.5 & 4,784 & 33.8 & 1,185 \\
\hline 11 and 12 & 23 and 24 & $\begin{array}{r}\text { NPK (calcium nitrate, dicalcium } \\
\text { phosphate, and potassium sul- } \\
\text { fate) } \ldots \ldots \ldots \ldots \ldots \ldots \ldots \ldots \ldots\end{array}$ & 13.75 & 482 & 273.0 & 9,568 & 33.8 & 1,185 \\
\hline
\end{tabular}

* Rate per acre on area basis; the soil-surface area in the oil drums was $2.74 \mathrm{sq} . \mathrm{ft}$.

the other a virgin Sierra loam containing ample available phosphate, from the University of California Citrus Experiment Station at Riverside. Enough of each soil was obtained to fill twelve 55-gallon containers, each soil being thoroughly mixed before filling the containers. The fertilizers used were calcium nitrate, dicalcium phosphate, and potassium sulfate. The phosphate and potassium sulfate were subsequently mixed throughout the soil of each of the cultures receiving these treatments. The nitrate was applied in solution to the top of the soil. At frequent intervals in the course of this experiment, subsequent applications of nitrate were given to those cultures receiving nitrogen, but no further phosphate or potassium fertilizer was added, save a surface application of dicalcium phosphate to the soil in culture 4 later in the experiment when this tree had become phosphorus-deficient; this was for the pur- 
pose of testing the diagnosis. The cultures were watered with distilled water. The experiment was set up in a screened enclosure out of doors.

Oats were grown in the containers during the first year (1934) in order to provide preliminary information on responses to the fertilizer.

On March 4, 1935, one-year-old budded navel-orange trees, especially selected for uniformity, were planted in the containers. The appearance of the trees in the Hanford fine sandy loam, three months after transplanting, is shown in figure 1. Tomatoes were also grown in the containers at this time to determine whether the phosphate which had been

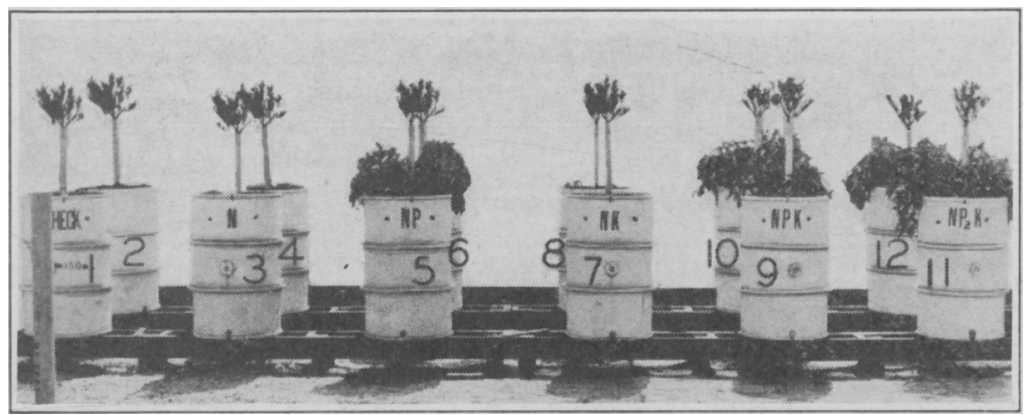

Fig. 1.-Young navel-orange trees three months after transplanting in differentially fertilized cultures. Two replicates. Fertilizer treatment was as follows: cultures 1 and 2 , no treatment; cultures 3 and'4, calcium nitrate; cultures 5 and 6, calcium nitrate and dicalcium phosphate; cultures 7 and 8, calcium nitrate and potassium sulfate; cultures 9 and 10 , calcium nitrate, dicalcium phosphate, and potassium sulfate; cultures 11 and 12, same as that for 9 and 10 save that twice as much dicalcium phosphate was used in these cultures. Note failure of interplanted tomatoes to grow in cultures which received no phosphate treatment.

applied seventeen months previously was still effective. Figure 1 shows that the added phosphate was still available and also demonstrates the extreme unavailability of the native phosphate of this soil for this plant; practically no growth was made in those cultures which received no phosphate. Subsequent trials with interplanted tomatoes gave similar results.

\section{DEVELOPMENT AND DIAGNOSIS OF PHOSPHORUS DEFICIENCY}

During the first three years (March, 1935, to March, 1938), no significant differences in growth of the citrus trees resulted from the differential fertilizer treatments in the Hanford soil, save for nitrogen deficiency in those cultures not receiving nitrate. ${ }^{5}$ The green fruits which

S This was true in the case of the Sierra loam soil as well. Subsequently the trees in the Sierra loam soil developed an acute sulfur deficiency, the effects of which are described in the succeeding paper (6). 
set in 1936 were picked; fruits which set in 1937, 1938, 1939, and 1940 were allowed to remain on the trees and ripen.

After the spring bloom in 1938, the four trees growing in the Hanford soil and receiving the nitrogen or nitrogen and potassium treatments (cultures 3, 4, 7, and 8) began to shed an abnormal number of leaves, as compared with the trees receiving phosphate. It was further noted that many of the falling leaves had burned areas and were of a dullgreen color with a bronze cast. The low availability of the phosphate of

TABLE 2

Phosphate in Hanford Soll after Four Years' Croppina, Compared With Phosphate of ORIGINal Soll

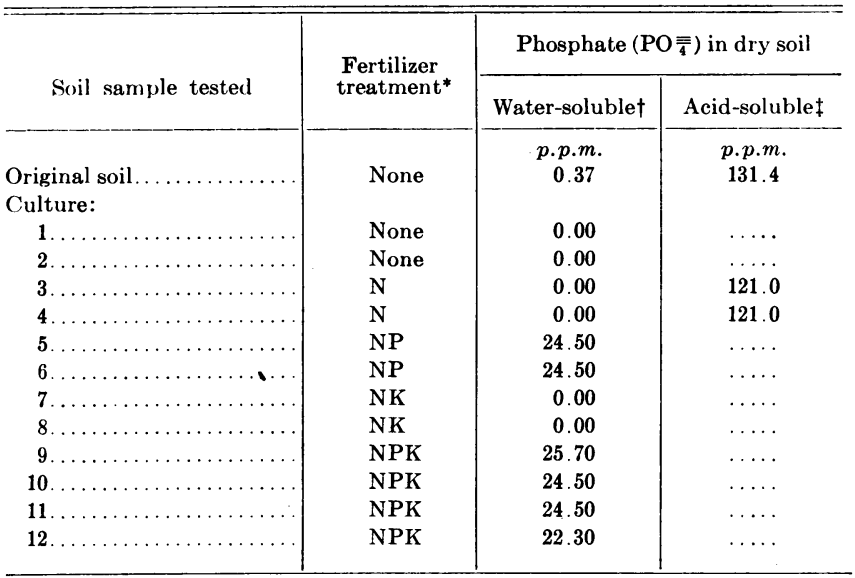

* For explanation of fertilizer treatment see table 1 (p. 162).

$\dagger$ Determination on 100 milliliters of a $1: 5$ water extract by the blue colorimetric method.

$\ddagger$ Determination by the Truog (17) method; these tests were run only on the original soil and on cultures 3 and 4 .

this soil immediately suggested phosphorus deficiency as the possible cause. Analyses of the woody tissue of one of these trees (no. 3) for inorganic phosphate $(5)^{6}$ showed only 23 p. p. m. $\mathrm{PO}_{4}^{\equiv}$, on a green-weight basis, whereas similar tissue from a phosphate-treated tree (no. 5) contained 250 p. p. m. PO $\overline{\overline{4}}$. Determination of total phosphorus in burned and abscised leaves from tree no. 3 showed 0.07 per cent as against 0.13 per cent in comparable leaves taken from tree no. 15 growing in the Sierra loam soil, which received the same fertilizer treatment (calcium nitrate) but had none of the phosphorus-deficiency symptoms.

Soil samples taken from all the Hanford soil cultures on September 29, 1938, together with a sample of the original soil, were tested

\footnotetext{
"Italic numbers in parentheses refer to "Literature Cited" at the end of this paper.
} 
for water-soluble phosphate. Determinations of acid-soluble phosphate, made by the Truog (17) method, were also run on the original soil and on samples from cultures 3 and 4 . The results of these tests are presented in table 2. Although the original soil contained a measurable amount of water-soluble phosphate, no trace was found in those cultures which did not receive phosphate treatment. On the other hand, there was almost as much acid-soluble phosphate present in cultures 3 and 4 as in the original uncropped soil, which indicates that the citrus trees had not materially reduced the reserve phosphate supply of this soil.

TABLE 3

Comparative Cross-sectional Areas of Trunks of Navel-Orange Trees Grown IN DIFFERENTIALLY FerTilized SoILs, 1937-1940

\begin{tabular}{|c|c|c|c|c|c|c|}
\hline \multirow[b]{2}{*}{ Trees } & \multirow{2}{*}{$\begin{array}{l}\text { Fertilizer } \\
\text { treatment* }\end{array}$} & \multicolumn{5}{|c|}{ Average cross-sectional area of tree trunks $\dagger$} \\
\hline & & $\begin{array}{c}\text { Dec. 28, } \\
1937\end{array}$ & $\begin{array}{c}\text { Sept. 24, } \\
1938\end{array}$ & $\begin{array}{c}\text { Oct. } 14, \\
1939\end{array}$ & $\underset{1940}{\operatorname{May}} 17$ & $\begin{array}{c}\text { Net increase } \\
1937-1940\end{array}$ \\
\hline 1 and 2 & None & $\begin{array}{c}\text { sq. } \mathrm{cm} \\
6.9\end{array}$ & $\begin{array}{c}s q . \mathrm{cm} \\
8.1\end{array}$ & $\begin{array}{c}s q . \mathrm{cm} \\
8.5\end{array}$ & $\begin{array}{c}\text { sq. } \mathrm{cm} \\
8.7\end{array}$ & $\begin{array}{l}s q . \mathrm{cm} \\
1.8\end{array}$ \\
\hline 3 and 4 & $\mathrm{~N}$ & 9.6 & 11.9 & 13.7 & 14.2 & 4.6 \\
\hline 5 and 6. & NP & 9.6 & 13.4 & 16.2 & 16.1 & 6.5 \\
\hline 7 and 8 & NK & 9.7 & 13.6 & 15.6 & 15.8 & 6.1 \\
\hline 9 and $10 \ldots$ & NPK & 9.2 & 13.2 & 16.7 & 17.7 & 8.5 \\
\hline 11 and $12 .$. & NPK & 9.6 & 14.1 & - $\quad 17.4$ & 18.6 & 9.0 \\
\hline
\end{tabular}

* For explanation of fertilizer treatment see table 1 (p. 162).

† Figures are averages of measurements at three permanently marked points (see fig. 2) on trunks of two trees in duplicate cultures.

Further evidence that the malnutrition noted was phosphorus deficiency was provided by the fact that phosphate applications to the surface of the soil of culture 4 in the summer of 1939 brought about definite tree recovery.

\section{EFFECT OF PHOSPHORUS DEFICIENCY ON GROWTH AND APPEARANCE OF TREES AND ON FRUIT}

The average cross-sectional areas of the trunks of the differentially fertilized trees in duplicate cultures, at various periods from December, 1937, to May, 1940, are shown in table 3. The measurements in 1937 were made before any symptoms of malnutrition had become evident. All save the nitrogen-deficient trees had made a very uniform growth up to this time. The subsequent retarded growth of the phosphorus-deficient trees is definitely shown by these data. This is more strikingly brought out by pictures of trees 3 and 5 , taken in the spring of 1939 (plate 2, $A$ and $B$ ). Color pictures of trees 3 and 5 , taken a year later (plate 1), show the continued decline of the phosphorus-deficient tree. 
Weak and limited new growth, premature abscission of older leaves, dieback of weakened twigs, together with a dull-green to bronze color of the foliage, were the more common features of this disorder. The leaves were small, somewhat thickened, and stood more upright in relation to the stem than normal leaves. No unusual twig, trunk, or root symptoms, such as splitting or gumming, have been observed to date.

Perhaps the best diagnostic symptom, though by no means the most conspicuous, is a burn which occurs on the older leaves. This is most pronounced in the spring after the emergence of the blossoms and new foliage.

From studies of phosphorus-deficient lemon plants grown from cuttings in the greenhouse in solution cultures, as well as from the aforementioned observations on bearing trees, it appears that the burn and premature abscission of older leaves takes place most prominently during periods when active terminal growth is being made. A seventeenmonth-old, phosphorus-deficient lemon plant and a healthy lemon plant of the same age, both grown in the greenhouse, are shown in figure 2. Note that the older leaves of the phosphorus-deficient plant have been shed and, also, that leaf size is somewhat reduced. At the time these pictures were taken, new terminal growth was continuing to appear on the plant lacking phosphorus, and the older leaves along the lower stem were, concurrently, being shed. Many, though by no means all, of the falling leaves showed burn; all had a bronzed, lusterless appearance. The effects of phosphorus deficiency on lemon plants grown in the greenhouse agree with those described by Haas (10) for similarly grown citrus plants.

Apparently, there is a translocation of phosphorus from the older to the developing leaves as the supply of phosphate becomes deficient. Tests for inorganic phosphate at various points along the stem of the phosphorus-deficient lemon plants grown in the greenhouse showed much higher amounts at the growing point than toward the base. The total phosphorus content of old leaves shed at a point 36 inches up the stem from the base of the plant was 0.062 per cent; that of leaves 72 iuches up the stem was 0.075 per cent; while that of green terminal leaves, 96 inches from the base, was 0.15 per cent. Corresponding leaves from healthy plants of similar age showed a total phosphorus content ranging from 0.15 to 0.25 per cent.

The burn noted on the leaves of the phosphorus-deficient trees often started as a discoloration (plate $1, E$ ), giving them somewhat of a watersoaked appearance. Shortly thereafter, this area died completely (plate $1, F$ and $G$ ). At this stage, the injury resembled certain types of salt burn; in fact, so far as appearance is concerned, leaves burned at the 
tip through phosphorus deficiency are indistinguishable from those injured by chloride. But, whereas the burned phosphorus-deficient leaves occur in greatest abundance in the spring, salt injury is more commonly seen in the fall and winter.

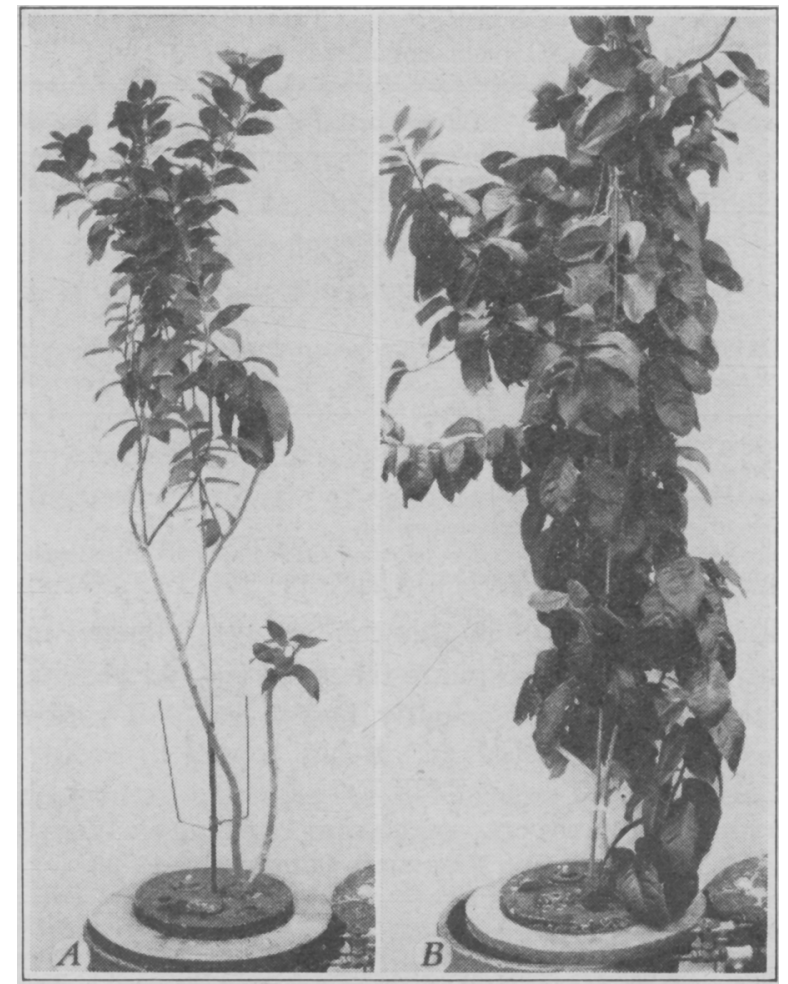

Fig. 2.-Seventeen-month-old lemon plants grown $(A)$ in phosphate-deficient solution and $(B)$ in complete nutrient solution. Note premature abscission of old leaves on the phosphorus-deficient plant. Both plants were grown in complete nutrient solution for thirteen months, after which the plant on the left $(A)$ was deprived of phosphate.

Although the four phosphorus-deficient navel-orange trees (nos. 3, 4,7 , and 8) blossomed profusely in the spring of 1938, no fruit was produced, in contrast to a good set of fruit on the six trees receiving phosphate. Very weak, sparse bloom has characterized these trees in subsequent years, and the spring vegetative cycle has been limited (plate $1, D$ and $C$ ). The failure of these trees to bear fruit during the three years after they became phosphorus-deficient is clearly shown in table 4. A record of the fruit produced on all the differentially fertilized trees of this experiment, from 1935 to 1941, is set forth in this table. 
Various quality studies were made on the fruits borne by the trees in all cultures in the year 1937-38, just preceding the onset of the phosphorus deficiency in cultures $3,4,7$, and 8 . The fruits were picked on

TABLE 4

Number of Fruits Borne by Navel-Orange Trees Grown in Differentially Fertilized Hanford Soll Cultures, 1935-1941

\begin{tabular}{|c|c|c|c|c|c|c|c|}
\hline \multirow{2}{*}{ Trees } & \multirow{2}{*}{$\begin{array}{c}\text { Fertilizer } \\
\text { treat- } \\
\text { ment }\end{array}$} & \multicolumn{6}{|c|}{ Total number of fruits on trees in replicate cultures } \\
\hline & & $1935-36$ & $1936-37 \dagger$ & $1937-38$ & $1938-39$ & $1939-40$ & 1940-41† \\
\hline 1 and $2 \ldots$ & None & 0 & 0 & 0 & 0 & 0 & 0 \\
\hline 3 and $4 \ldots$ & $\mathrm{N}$ & 0 & 9 & 10 & 0 & 0 & 0 \\
\hline 5 and $6 \ldots$ & NP & 0 & 1 & 10 & 20 & 20 & 109 \\
\hline 7 and $8 \ldots$ & NK & 0 & 6 & 13 & 0 & 2 & 0 \\
\hline 9 and $10 \ldots$ & NPK & 0 & 9 & 10 & 37 & 37 & $46 \S$ \\
\hline 11 and $129 . \ldots \ldots$ & NPK & 0 & 3 & 4 & 5 & 28 & 50 \\
\hline
\end{tabular}

* For explanation of fertilizer treatment see table 1 (p. 162 ).

$\dagger$ Fruits picked green June 22, 1936.

$\ddagger$ Green fruits on trees August 19, 1940.

$\$$ Fruits on tree 10 only; tree 9 was harvested earlier.

These two trees showed periodic symptoms of malnutrition, owing to the heavy phosphate applications given at the beginning of the experiment, and fruit production on these trees was subnormal.

February 4, 1938, and while at this time no symptoms of malnutrition were evident in the non-phosphate-treated trees, it was just after the spring blossom that the abnormally heavy leaf fall referred to took

TABLE 5

Characteristics of Mature Navel Oranges Produced on Trees Grown in DifTERENTtally Fertilized CULtures, 1937-38

\begin{tabular}{|c|c|c|c|c|c|c|c|c|}
\hline 'Trees & $\begin{array}{c}\text { Fertilizer } \\
\text { treat- } \\
\text { ment }\end{array}$ & $\begin{array}{c}\text { Total } \\
\text { fruits } \\
\text { produced } \\
\text { and } \\
\text { tested }\end{array}$ & Color of rind & $\begin{array}{c}\text { Average } \\
\text { rind } \\
\text { thickness, } \\
\text { per- } \\
\text { centage } \\
\text { of total } \\
\text { diameter }\end{array}$ & $\begin{array}{c}\text { Average } \\
\text { per- } \\
\text { centage } \\
\text { of juice }\end{array}$ & $\begin{array}{c}\text { Average } \\
\text { total } \\
\text { solids, } \\
\text { degrees } \\
\text { Brix at } \\
17.5^{\circ} \mathrm{C}\end{array}$ & $\begin{array}{c}\text { Average } \\
\text { anhy- } \\
\text { drous } \\
\text { citric acid } \\
\text { in juice }\end{array}$ & $\begin{array}{c}\text { Average } \\
\text { total } \\
\text { phos- } \\
\text { phorus } \\
\text { in juice }\end{array}$ \\
\hline 1 and 2 & None & $\begin{array}{c}\text { number } \\
0\end{array}$ & & $\begin{array}{c}\text { per cent } \\
\ldots\end{array}$ & $\begin{array}{c}\text { per cent } \\
\ldots .\end{array}$ & $\begin{array}{c}{ }^{\circ} \text { Brix } \\
\ldots .\end{array}$ & $\begin{array}{c}\text { per cent } \\
\ldots\end{array}$ & $\begin{array}{c}\text { per cent } \\
\ldots \ldots\end{array}$ \\
\hline 3 and 4 & $\mathrm{~N}$ & 10 & Deep orange & 9.7 & 36.7 & 13.2 & 1.14 & 0.029 \\
\hline 5 and 6 & NP & 10 & Yellow orange & 8.1 & 40.5 & 13.5 & 0.89 & .064 \\
\hline 7 and 8 & NK & 13 & Deep orange & 8.2 & 37.8 & 13.2 & 1.05 & .036 \\
\hline 9 and 10 & NPK & 10 & Yellow orange & 7.6 & 42.0 & 13.3 & 0.77 & .072 \\
\hline 11 and 12 & NPK & 4 & Yellow orange & 7.0 & 39.8 & 13.1 & 0.92 & 0.078 \\
\hline
\end{tabular}

* For explanation of fertilizer treatment see table 1 (p. 162).

place. Since these trees must have been in the incipient stage of phosphorus deficiency at this time, the character of the fruit which matured is perhaps suggestive. The more pertinent data are reported in table 5 and show that fruits borne by the trees receiving no phosphate were characterized by a deeper orange color, thicker rind, less juice, higher 
acid, and lower phosphorus content than the fruits from the phosphatetreated trees. The potassium treatment also apparently reduced rind thickness somewhat.

Only two fruits have since been produced on the phosphorus-deficient trees (table 4). Like the earlier ones, these fruits were deep orange in color. They had thick, coarse rinds, were decidedly lacking in juice, and were puffy. The fruits from the phosphate-treated trees during this same year, examined on the same date, had much thinner and smoother rinds, were very juicy, and showed no puffiness. More data will be needed to characterize definitely the effects of phosphorus deficiency on citrus fruit, but the preceding information is suggestive and fits in with existing evidence as to the influence of phosphorus on fruit quality $(1,2)$.

\section{MINERAL COMPOSITION OF PHOSPHORUS-DEFICIENT ORANGE TREES}

In order to characterize further the effects of phosphorus deficiency, inorganic analyses were made of various parts of phosphorus-deficient tree no. 8 and of healthy tree no. 9. These two trees were removed from the cultures in July, 1940. Samples of leaves, pencil-sized twigs, trunks, pencil-sized roots, and fine roots were washed in tap water and rinsed in distilled water. The bark was separated from the twigs, trunk parts, and pencil-sized roots; the interior woody parts were ground in a pencil sharpener while still green; and the bark, leaves, and fine roots, when air-dry, were ground in a Wiley mill. The samples were dried at $105^{\circ} \mathrm{C}$, and analyses were made according to accepted procedures. The results are shown in table 6.

All parts of the phosphorus-deficient tree were low in phosphorus. The greatest contrast in the total phosphorus of the deficient and healthy plants was found in the bark and wood of the twigs, trunk, and coarse roots; the least difference was found in the young leaves. The older leaves were lower in phosphorus than the young leaves. These results indicate that the bark or woody tissue is more expressive as regards phosphorus status and more critical for diagnostic purposes than the leaves.

With the exception of the trunk wood, the nitrogen content of all parts of the phosphorus-deficient tree was higher than that of corresponding parts of the healthy plant. The differences in nitrogen content were most pronounced in the old leaves and the twig bark; and while the differences in the young leaves, interior root wood, and fine roots are small, they are probably significant. This is in harmony with the findings of many other investigators, who have shown that phosphorusdeficient plants are high in nitrogen and that nitrogen-deficient plants are high in phosphorus. 
The potassium content of the young and old leaves and of the fine roots taken from the phosphorus-deficient tree was also higher than that of corresponding parts of the healthy tree; but in the other plant parts, the condition was just the reverse. The calcium and ash contents of the

TABLE 6

Comparative Inorganic Composition of Parts of Phosphorus-deficient and Healthy Navel-Orange Trees

\begin{tabular}{|c|c|c|c|c|c|c|c|c|c|}
\hline \multirow{2}{*}{$\begin{array}{l}\text { Part of tree and } \\
\text { condition }\end{array}$} & \multicolumn{9}{|c|}{ Constituents of dry matter, at $105^{\circ} \mathrm{C}$} \\
\hline & Ash & $\mathrm{Ca}$ & Mg & $\mathrm{K}$ & $\mathrm{Na}$ & Cl & $\mathrm{N}$ & $\mathbf{P}$ & $\mathbf{S}$ \\
\hline \multirow{2}{*}{\multicolumn{10}{|c|}{ per cent $\mid$ per cent $\mid$ per cent $\mid$ per cent $\mid$ per cent $\mid$ per cent $\mid$ per cent $\mid$ per cent $\mid$ per cent }} \\
\hline & & & & & & & & & \\
\hline Phosphorus-deficient. & 12.55 & 2.84 & 0.18 & 2.56 & 0.08 & 0.19 & 3.46 & 0.14 & 0.26 \\
\hline Healthy............. & 14.23 & 4.34 & .12 & 1.55 & .02 & .39 & 3.38 & .18 & .23 \\
\hline \multicolumn{10}{|l|}{ Old leaves: } \\
\hline Phosphorus-deficient. & 15.63 & 4.14 & .18 & 2.50 & .06 & .21 & 5.00 & .05 & .23 \\
\hline Healthy............ & 22.80 & 8.17 & .09 & 0.80 & .04 & .35 & 1.70 & .11 & .26 \\
\hline \multicolumn{10}{|l|}{ Twig bark: } \\
\hline Phosphorus-deficient & 12.76 & 4.23 & .08 & 0.43 & .08 & .09 & 3.03 & Trace & .11 \\
\hline Healthy............. & 15.47 & 5.22 & .12 & 0.62 & .05 & .14 & 1.65 & .28 & .27 \\
\hline \multicolumn{10}{|l|}{ Twig wood: } \\
\hline Phosphorus-deficient. & 4.89 & 1.73 & .05 & 0.17 & .05 & .11 & 0.85 & Trace & .09 \\
\hline Healthy............. & 4.12 & 1.26 & .08 & 0.24 & .04 & .14 & 0.72 & .22 & .12 \\
\hline \multicolumn{10}{|l|}{ Trunk bark: } \\
\hline Phosphorus-deficient & 12.41 & 3.20 & .44 & 0.51 & .06 & .09 & 1.97 & Trace & .63 \\
\hline Healthy............. & 13.15 & 4.40 & .35 & 0.66 & .05 & .11 & 1.64 & .24 & .18 \\
\hline \multicolumn{10}{|l|}{ Trunk wood: } \\
\hline Phosphorus-deficient. & 3.26 & 1.13 & .06 & 0.15 & .05 & .14 & 0.46 & Trace & .22 \\
\hline Healthy............. & 2.49 & 0.69 & .08 & 0.21 & .03 & .14 & 0.60 & .16 & .11 \\
\hline \multicolumn{10}{|l|}{ Root bark: } \\
\hline Phosphorus-deficient. & 9.22 & 2.79 & .17 & 0.52 & .08 & .32 & 2.66 & .01 & .11 \\
\hline Healthy ............ & 11.00 & 3.26 & .18 & 0.75 & .02 & .40 & 2.15 & .24 & .20 \\
\hline \multicolumn{10}{|l|}{ Root wood: } \\
\hline Phosphorus-deficient. & 2.37 & 0.77 & .07 & 0.06 & .05 & .11 & 0.70 & .01 & .05 \\
\hline Healthy $\ldots \ldots \ldots \ldots$ & 2.64 & 0.73 & .09 & 0.18 & .05 & .12 & 0.66 & .16 & .08 \\
\hline \multicolumn{10}{|l|}{ Fine roots: } \\
\hline Phosphorus-deficient & 18.40 & 4.32 & .22 & 0.75 & .02 & .35 & 2.03 & .12 & .12 \\
\hline Healthy.............. & 28.23 & 4.46 & 0.22 & 0.59 & 0.04 & 0.32 & 1.95 & 0.25 & 0.14 \\
\hline
\end{tabular}

young and old leaves and of the twig, trunk, and root bark, as well as that of the fine roots, of the phosphorus-deficient tree were definitely lower than that of corresponding parts of the healthy tree; but that of twig and trunk wood was somewhat higher. There was no significant difference in the calcium or ash of the root wood. The differences in magnesium content of parts of the two trees were small; the greatest differ- 
ences were found in leaves and in trunk bark, the phosphorus-deficient parts showing the higher content. In most cases, the sodium, chlorine, and sulfur contents were not much affected.

The burn which occurs on many of the older leaves and which, in the case of some leaves, is indistinguishable from chloride injury, is clearly not the result of chloride accumulation. The high nitrogen and potassium content of these old leaves, coupled with the observations of Eckerson (8), that phosphorus-starved plants store nitrate, suggests that the burn may be a result of excessive potassium nitrate accumulation. This possibility is being explored. Breakdown and disorganization of the cell protoplasm were noted by Reed (16) and Eckerson (8) in their studies of the effects of acute phosphorus deficiency.

\section{DEVELOPMENT OF MANGANESE-DEFICIENCY SYMPTOMS ON PHOSPHORUS-DEFICIENT TREES}

A further observation of considerable interest was the appearance of leaf symptoms of manganese deficiency on the summer-cycle growth of all the phosphorus-deficient trees in 1939 and again in 1940. When sprayed with manganese chloride, such leaves became green. A twig from a phosphorus-deficient tree, showing the typical manganese-deficiency leaf patterns $(7)$ and the prompt recovery induced on a single leaf by painting with a dilute solution of manganese chloride, is presented in plate $2, C$. The trees receiving phosphate showed no such symptoms.

Lyon $(13,14)$ has found that respiration and the production of carbon dioxide in green plants is pronouncedly increased by the use of phosphates, and Eckerson (8) has shown that reductase activity, as evidenced by nitrate accumulation, is decreased when phosphate is lacking. That phosphate is intimately linked with the vital activities of cells is indicated by the work of these and other investigators. It seems logical to infer that the appearance of manganese deficiency in the phosphorusdeficient trees of this experiment was owing to the decreased respiration of plant roots, which limited the production of carbon dioxide accordingly and consequently diminished solvent action on the sparingly soluble manganese compounds of this calcareous soil. That the manganese deficiency noted is a result of decreased solvent action of plant roots rather than a result of failure to utilize manganese after it has gained entrance into the plant is indicated (1) by the fact that manganese applications to the leaf brought about recovery; and (2) by the observations that the spring growth, in contrast to that of the summer and fall cycles, in 1939 and again in 1940, showed no manganese-deficiency symptoms. The trees were evidently able to absorb and store enough manga- 
nese during the winter period, when vegetative growth is at a minimum, to suffice for the spring cycle.

\section{DISCUSSION}

While the phosphorus-deficient citrus trees of this experiment showed none of the anthocyanin pigmentation which is common on the stems and leaves of many plants lacking phosphorus $(3,8,9,11,12,15,18)$, many characters similar to the effects of a deficiency of this element on other plants were apparent. Of these, greatly reduced growth rate, small leaves, lack of branching, continued terminal growth (weak and slow, however) at the expense of the older leaves, and bronze or dull-green color of old leaves were the most evident.

On tobacco, Karraker and Bortner (12) and McMurtrey (15) describe a necrotic spotting of the older leaves caused by phosphorus deficiency, though McMurtrey states that this character does not always develop. With citrus, the burn on older leaves occurs chiefly during periods when terminal growth is being made. Despite the somewhat irregular advent of this injury, it is perhaps the most diagnostic symptom; for sparse growth, open trees, and dull-green leaves may result in citrus from other causes also. Though the burn on some leaves resembles chloride injury, the latter occurs more commonly in the fall and winter, while the necrosis due to the lack of phosphorus is more prominent in the spring, after the emergence of the bloom and new-cycle growth.

Leaf analysis provides a fairly reliable means of distinguishing between the two injuries, since chloride-injured leaves show accumulations of chloride, whereas leaves burned as a result of phosphorus deficiency show no chloride accumulation and are distinctly subnormal in phosphorus content. Analyses of various parts of trees lacking phosphorus have also shown that the bark and woody tissue of pencil-sized twigs are exceedingly low in both total and inorganic phosphorus. These tests, together with the other symptoms described, would appear to be sufficient for diagnostic purposes when the deficiency is acute. As in other deficiencies, however, confirmatory tests, such as soil and plant treatments with phosphorus, should be undertaken as a final check.

The development of acute phosphorus deficiency in citrus grown in soil cultures has raised the question as to the possible phosphate reeds of citrus grown under field conditions on comparable soils. A recent survey has been made of commercial citrus groves located on soils similar to the Hanford sandy loam used in this experiment. None of the trees in these groves showed any of the symptoms of phosphorus deficiency herein described, and tests for inorganic phosphate in the woody tissue of a number of the trees showed definitely higher amounts than were 
found in the phosphorus-deficient trees of the experimental cultures. The acute deficiency which developed under the conditions of this experiment is probably accounted for by the restricted volume of soil available for root development. Under field conditions, with a much larger body of soil available for root growth, it is unlikely that acute phosphorus deficiency would develop. Moreover, the soils of the majority of commercial orchards in California (4) have been found to contain substantial accumulations of phosphate, owing to the past use of manures and mixed fertilizers. The continued use of manures or bulky organic materials will no doubt supply adequate phosphate for citrus needs, even though the phosphate of the original soil may be somewhat low.

\section{SUMMARY}

In connection with a fertilizer experiment on a calcareous Hanford fine sandy loam with young navel-orange trees in 55-gallon containers, an acute phosphorus deficiency developed in those trees receiving nitrogen or nitrogen and potassium but no phosphate.

The onset of this disorder was sudden. An abnormal shedding of leaves, which occurred just after the spring bloom in 1938, three years after planting, was the first indication of malnutrition. Some of the leaves showed burned areas, and many had a dull-green, bronzed, lusterless appearance. Little new growth was made subsequently, and the leaves were somewhat undersized, though not conspicuously so. Spring blossoms in the two succeeding years (1939 and 1940) were meager, and fruit failed to set, save for one fruit each on two trees during the year 1939. These two fruits were small in size, some puffiness was evident, and the juice content was low. With the exception of some dieback, no abnormal twig, trunk, or root symptoms developed. The inorganic and total phosphorus contents of all parts of the tree were subnormal; phosphorus in the bark and woody tissue was especially low. Fruit which matured on the phosphorus-deficient trees just prior to the development of leaf symptoms had a deeper orange color, thicker rind, and less juice than the fruit on the phosphate-treated trees.

A secondary manganese deficiency developed in the phosphorus-deficient trees. This was thought to be the result of the decreased solvent power of plant roots for the sparingly soluble manganese compounds of this soil, occasioned by diminished root respiration.

A survey of the trees of commercial citrus groves located on soils comparable to that used in this experiment showed no symptoms of phosphorus deficiency. Probably the deficiency which occurred in the experimental cultures resulted in part from the restricted root development owing to the limited quantity of soil available for root expansion. 


\section{ACKNOWLEDGMENTS}

The authors are indebted to Mr. David Rayner for effective work rendered in the culture and care of the experimental trees; they are also indebted to Mr. George F. Liebig, Jr., and Mr. Basil Followell for miscellaneous help given from time to time. This assistance is acknowledged with thanks. 


\section{LITERATURE CITED}

1. Allwright, W. J.

1936. Progress report on the fertiliser trials at Rustenburg, Western Transvaal. Citrus Grower 45:3-5, 7 .

2. ANDERSSEN, F. G.

1937. Citrus manuring-its effect on cropping and on the composition and keeping quality of oranges. Jour. Pomol. and Hort. Sci. 15(2):117-59.

3. Blake, M. A., G. T. Nightingale, and O. W. Davidson.

1937. Nutrition of apple trees. New Jersey Agr. Exp. Sta. Bul. 626:1-41.

4. Chapman, H. D.

1934. The phosphate of southern California soils in relation to citrus fertilization. California Agr. Exp. Sta. Bul. 571:1-22.

5. Chapman, H. D.

1935. Inorganic phosphate in green plant tissue as a measure of phosphate availability. Soil Sci. $39: 111-22$.

6. Chapman, H. D., and S. M. Brown.

1941. The effects of sulfur deficiency on citrus. Hilgardia 14(4):183-201.

7. Chapman, H. D., George F. Liebig, Jr., and E. R. Parker.

1939. Manganese studies [on] California soils and citrus leaf symptoms of deficiency. California Citrog. 24(12):427, 454; 25(1):11, 15.

8. Eckerson, SophIA H.

1931. Influence of phosphorus deficiency on metabolism of the tomato (Lycopersicum esculentum Mill.). Boyce Thompson Inst. Contrib. 3:197-218.

9. Fisher, Paul Lewis.

1935. Responses of the tomato in solution cultures with deficiencies and excesses of certain essential elements. Maryland Agr. Exp. Sta. Bul. 375:283-98.

10. HAAS, A. R. C.

1936. Phosphorus deficiency in citrus. Soil Sci. 42:93-117.

11. Hoagland, D. R., and W. H. Chandler.

1932. Some effects of deficiencies of phosphate and potassium on the growth and composition of fruit trees under controlled conditions. Amer. Soc. Hort. Sci. Proc. 29:267-71.

12. KARRAKer, P. E., and C. E. Bortner.

1933. Symptoms of phosphorus deficiency in Turkish tobacco. Amer. Soc. Agron. Jour. 25(8):556-58.

13. Lyon, Chardes J.

1923. The effect of phosphates on respiration. Jour. Gen. Physiol. 6:299-306.

14. Lyon, Charles J.

1927. The rôle of phosphate in plant respiration. Amer. Jour. Bot. 14:274-83.

15. MCMURTREY, J. E., JR.

1938. Symptoms on field-grown tobacco characteristic of the deficient supply of each of several essential chemical elements. U. S. Dept. Agr. Tech. Bul. 612:1-30.

16. REED, Howard SPRAGUE.

1907. The value of certain nutritive elements to the plant cell. Ann. Bot. [London] 21:501-43. 
17. TruOG, E.

1930. The determination of the readily available phosphorus of soils. Amer. Soc. Agron. Jour. 22:874-82.

18. Wallace, $\mathrm{T}$.

1930. Some effects of deficiencies of essential elements on fruit trees. Ann. Appl. Biol. 17:649-57. 


\section{PLATES}




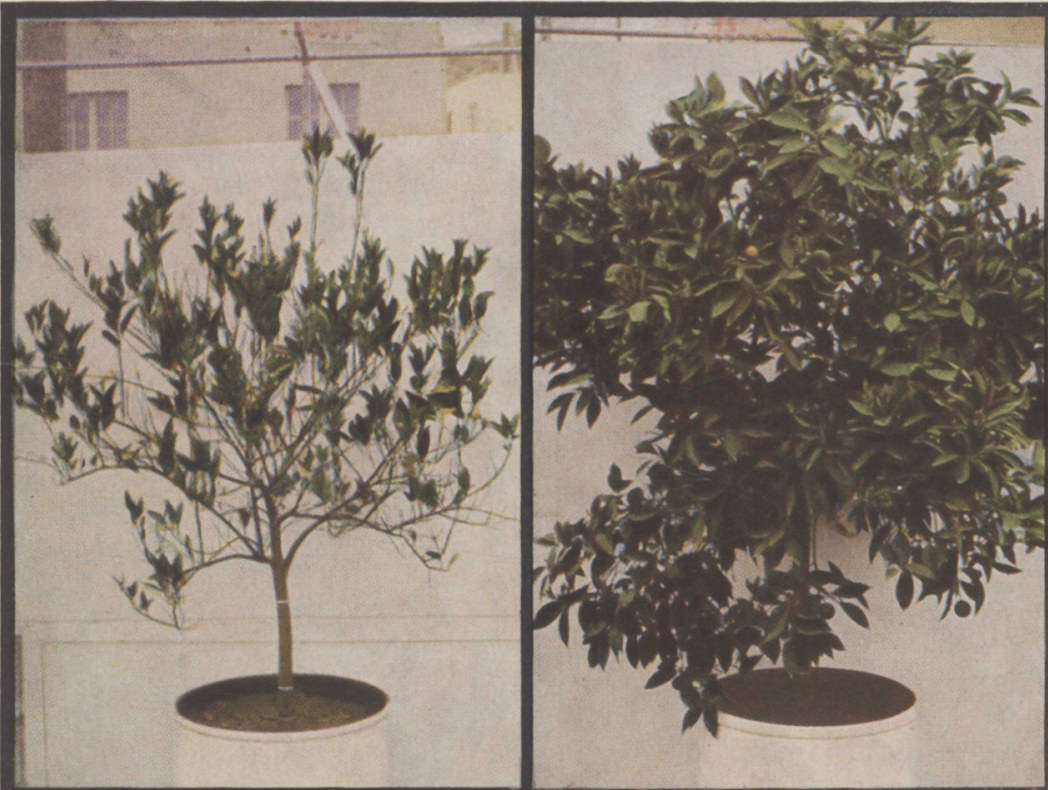

C
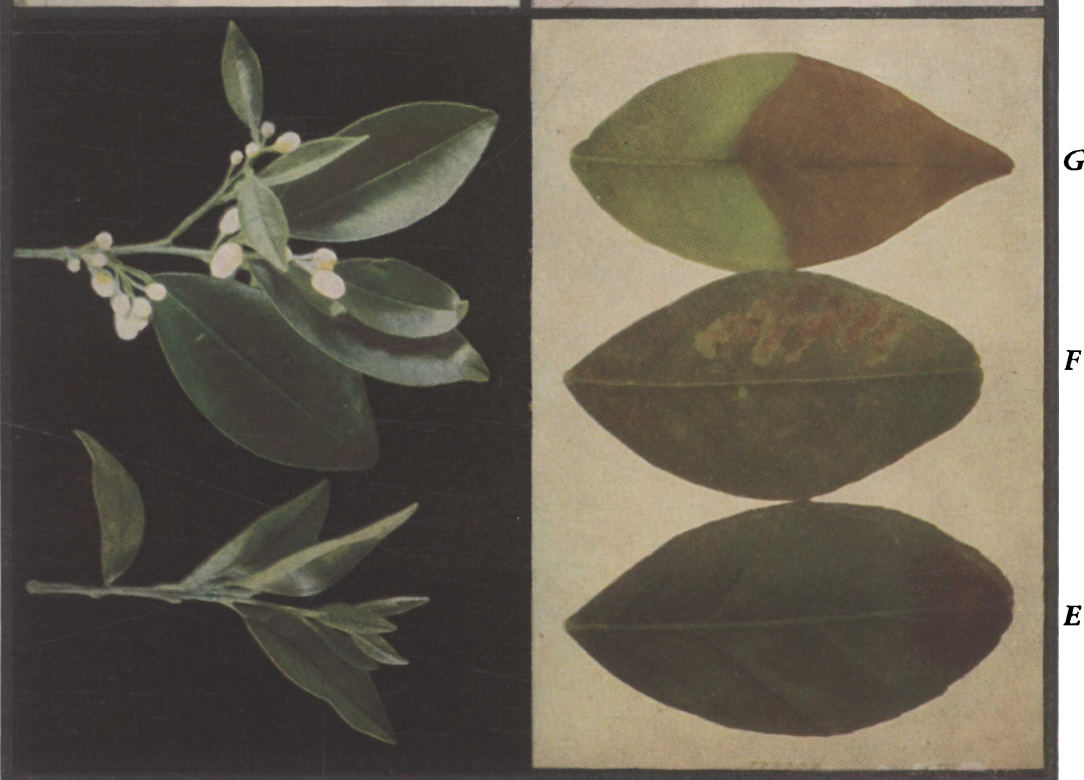

$D$

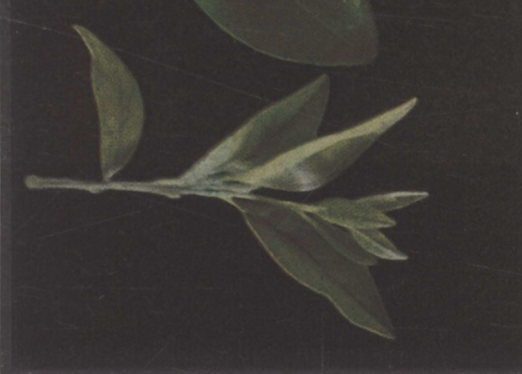

Plate 1.-Phosphorus deficiency of navel-orange tree, shoots, and leaves: $A$, five-year-old phosphorus-deficient tree; $B$, healthy tree, same age; $C$, healthy shoot; $D$, phosphorus-deficient shoot showing small, bronzed, old leaves, lack of bloom, and weak new-cycle growth; $E-G$, phosphorus-deficient leaves, dull green to bronze in color, showing various types of burn on old leaves. 


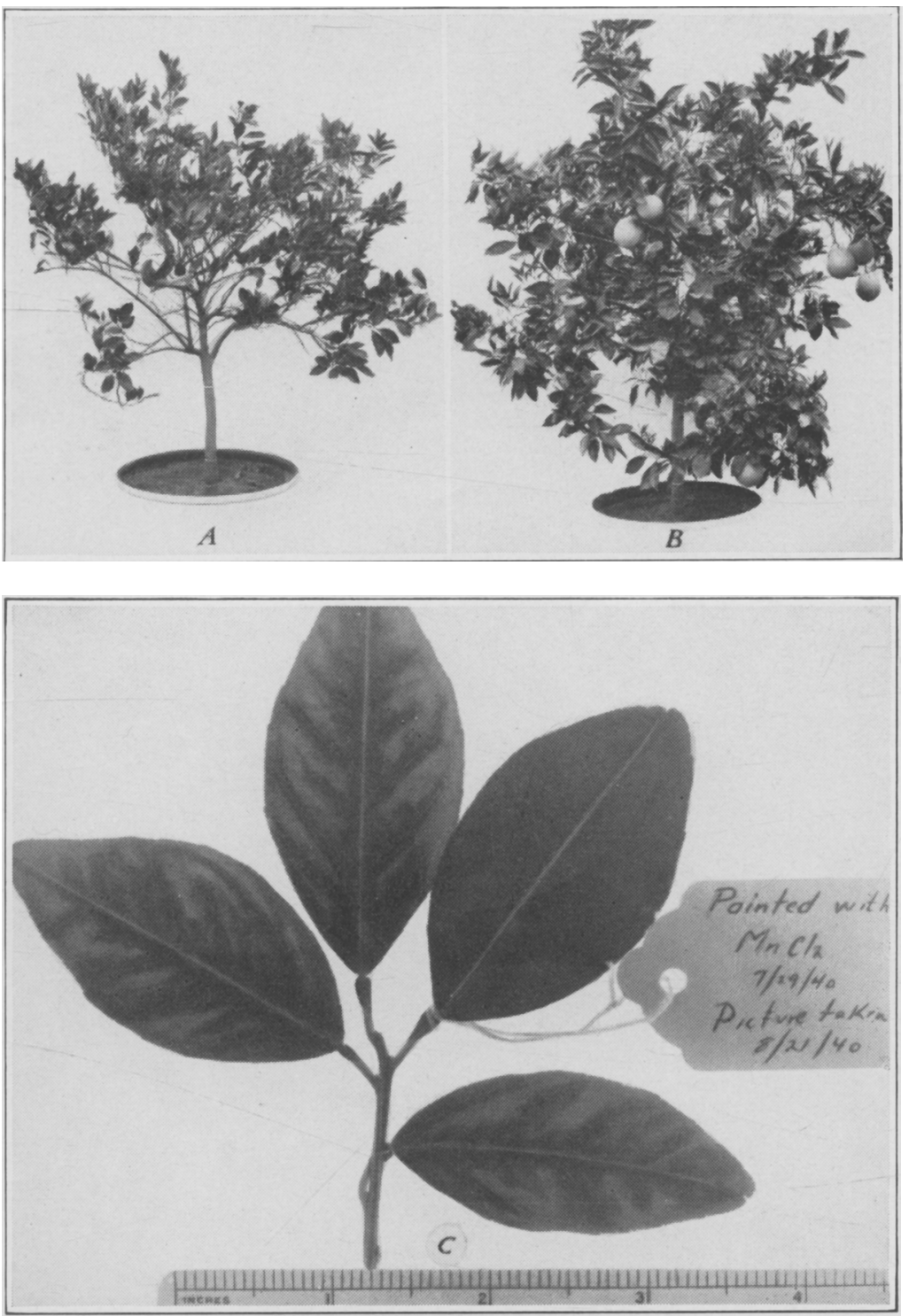

Plate 2.-A, Four-year-old phosphorus-deficient navel-orange tree (no. 3), showing reduced growth, sparse foliage, dead wood, and lack of fruit. $B$, Healthy tree of like age (no. 5). Both photographed February, 1939. $O$, Manganese-deficient navel-orange leaves which developed on the summer-cycle growth of a phosphorus-deficient tree. The tagged leaf became green less than a month after being painted with a solution of manganese chloride containing 5 milligrams of manganese per milliliter. 